\title{
PRIROČNIK ZA LABORATORIJSKE ANALIZE PRSTI V GEOGRAFIJI
}

Ana VOVK KORŽE in Franc LOVRENČAK, Ljubljana, 200I, Oddelek za geografijo Filozofske fakultete Univerze v Ljubljani, 49 strani (ISBN 96I-227-099-6)

Davnega leta 1979 je dr. Franc Lovrenčak izdal priročnik z naslovom Laboratorijske analize prsti (Laboratorijski priročnik za geografe). Nastal je kot posledica vedno večje uveljavitve analitičnih metod $\mathrm{v}$ geografiji in možnosti kvantifikacije pedogeografskega proučevanja. $\mathrm{S}$ tem so takratni uporabniki priročnika dobili možnost pridobivanja dragocenih podatkov, ki so jih nato uporabili pri nadaljnjemu delu in razlagi procesov v pokrajini. Priročnik je celih 22 let ostal edino vodilo v slovenskem jeziku za analitično proučevanje prsti, ki so ga uporabljale generacije študentov, učiteljev in drugih.

Po tolikem času se je pokazala potreba po posodobitvi in nadgradnji obstoječega priročnika. Razvoj znanosti je šel naprej tudi na področju proučevanja prsti in so se metode prilagodile novim znanjem, zahtevnejšim aparaturam, število merjenih parametrov se je bistveno povečalo in zahtevana je vedno večja natančnost zaradi možnosti računalniške obdelave pridobljenih podatkov. Poleg tega se je pojavilo tudi veliko število povsem novih analiz. Rezultat takšnih teženj je »Priročnik za laboratorijske analiza prsti v geografiji,« avtorjev dr. Ane Vovk Korže in dr. Franca Lovrenčaka, ki na enem mestu predstavlja tiste fizikalne in kemijske analize za preučevanje prsti, ki so v geografiji že ustaljene, dodane pa so še nekatere nove, ki pomembno prispevajo k spoznavanju prsti.

S priročnikom sta avtorja želela prikazati in ovrednotiti samo tiste analize prsti, ki jih lahko izvajamo v geografskem laboratoriju. Niso pa vključene specialne kemijske, fizikalne in biološke analize prsti, ki so bodisi zahtevne za izvedbo bodisi so rezultati analiz ozko strokovni.

Priročnik je razdeljen na 5 vsebinskih sklopov. Metodološki napotki za uporabo priročnika vpeljejo uporabnika $v$ način dela ter predstavijo sam priročnik. Naslednji, sila pomemben sklop se ukvarja s pripravo prsti za analizo v laboratoriju. Na tem mestu se seznanimo $\mathrm{z}$ varnostnimi ukrepi v laboratoriju, predvsem pa kako ravnamo z vzorci še preden jih prinesemo iz terena $\mathrm{v}$ laboratorij ter katere analize naj izberemo, da bomo dobili interpretabilne in primerljive rezultate.

Nato sledi jedro priročnika - poglavji ki obravnavata pomembne fizikalne in kemijske postopke za analizo prsti. Nekaj analiz je klasičnih in jih poznamo že iz preteklosti (mehanska analiza, določanje barve prsti in obstojnosti strukturnih agregatov, analiza kalcijevega karbonata, merjenje reakcije prsti itd.), nekateri postopki pa so posodobljeni in izpopolnjeni (določanje deleža skeleta in organskih snovi v prsti). Veliko vrednost predstavljajo analize, ki so geografom predstavljene prvič. Gre za analize por v prsti, predvsem zračno vodnih lastnosti ter analizo sorptivnega dela prsti (merjenje kationske izmenjalne kapacitete).

Vsako podpoglavje, ki obravnava posamezno analizo, predstavi namen in natančen opis metode, pripomočke in reagente, ki jih potrebujemo za izvedbo in podroben, korak po koraku opisan postopek, ki pripelje uporabnika do želenega rezultata. Daleč največjo bogastvo pa predstavlja zaključek podpoglavja, ki v obliki interpretacije rezultatov, na razumljiv način 
ovrednoti vsako analizo posebej ter pomen pridobljenih rezultatov. S tem se priročnik bistveno razlikuje od ostalih in si upravičeno zasluži ime geografski.

Zadnje poglavje obravnava značilnosti nekaterih tipov prsti v Sloveniji in njihove fizikalne in kemijske lastnosti. V obliki preglednic so na nazoren način prikazani analizirani parametri za posamezne tipe prsti, posebej ločeni po horizontih, kar uporabniku priročnika močno olajša interpretacijo rezultatov lastnih analiz. Poleg tega je priložena tudi karta prsti v Sloveniji.

Priročnik za laboratorijske analize prsti v geografiji je v prvi vrsti namenjen študentom geografije, kot pomoč pri praktičnemu delu v laboratoriju v okviru predmeta pedogeografija. Namenjen pa je tudi vsem posameznikom, ki jih zanimajo prsti, kot del pokrajine in bi jih želeli še natančneje spoznati.

Vse analize so preproste in ne zahtevajo ozko specializiranih ter dragih pripomočkov in reagentov. Večino le-teh je mogoče najti v vsakem srednješolskem laboratoriju zato bo priročnik dobrodošel tudi profesorjem geografije na srednjih šolah pri raziskovalnemu delu in pripravah na maturo.

Priročnik razpolaga s seznamov virov in literature, ki zahtevnejšega uporabnika napotijo k nadaljnjemu študiju in iskanju bolj specializiranih ter zahtevnejših metod. Priročnik je tudi bogato opremljen s slikovnim gradivom in preglednicami, kar ga naredijo še razumljivejšega, prijaznejšega in preprostega za uporabo.

Blaž Repe 